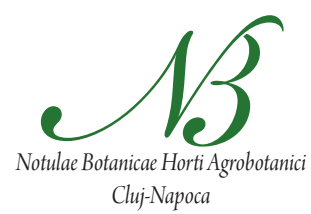

\title{
Fruit Quality and Phytochemical Attributes of Some Apricot (Prunus armeniaca L.) Cultivars as Affected by Genotypes and Seasons
}

\author{
Oguzhan CALISKAN*, Safder BAYAZIT, Ahmet SUMBUL \\ University of Mustafa Kemal, Faculty of Agriculture, Department of Horticulture, 31034, Antakya, \\ Hatay,Turkey; caliskanoguzhan@gmail.com ( ${ }^{*}$ corresponding author)
}

\begin{abstract}
This study was conducted over two growing seasons (2010 and 2011) to evaluate effects on fruit quality and phytochemical properties of new Turkish cultivars, hybrid between Irano-Caucasian- and European eco-geographic groups, and some important apricot cultivars in the eastern Mediterranean region of Turkey. Fruit quality characteristics, sensory traits, and phytochemical parameters were investigated. The data showed that considerable variation existed in fruit quality and phytochemical properties of Turkish, and foreign apricot cultivars based on genotypes and growing seasons. The new hybrid cultivar 'Çağataybey' contained the highest total soluble solid content (14.6\%), rich total phenolic (93.9 mg GAE $\left.100 \mathrm{~g}^{-1} \mathrm{fw}\right)$, and total antioxidant capacity levels $\left(9.8 \mathrm{mmol} \mathrm{Fe}{ }^{2+} \mathrm{kg}^{-1} \mathrm{fw}\right)$, and $>50 \%$ of blush color on the fruit peels among the cultivars. The fructose and sucrose values showed positively significant correlations with total phenolics ( $r=0.55$ and $r=0.69$, at $p<0.05$, respectively). The authors had estimated that the data will be useful for breeding studies to improve fruit quality and nutritional contents of apricot cultivars.
\end{abstract}

Keywords: cultivar, growing season, Prunus armeniaca, total phenolics, total antioxidant capacity

\section{Introduction}

Apricot (Prunus armeniaca L.) is a popular temperate zone fruit and one of the most important Prunus species grown in the world. It is highly appreciated by consumers, as the fruit exhibits a perfect balance between sugars and organic acids, combined with a strong and rich aroma (Gurrieri et al., 2001). Primarily, it is consumed fresh and in smaller amounts processed to juice, puree, jam, and dried fruit (Radi et al., 1997; Schmitzer et al., 2011). The European and Mediterranean countries, i.e. Turkey, Spain, Italy, France, and Greece, where many local cultivars are sown, represent $>75 \%$ of the world production of apricots (Leccese et al., 2010). The apricot varieties cultivated in this area, except for Turkey, belongs to the European ecogeographical group. This group is the most recent and the least variable (Badenes et al., 1998). These are well-adapted to specific climatic conditions and characterized by high variation in terms of visual traits, and the content of primary and secondary metabolites as well as other nutritional constituents (Drogoudi et al., 2008). Irano-Caucasian ecogeographical group of apricots showed a wide variation based on fruit quality characteristics, harvest season, and yield per tree (Asma and Ozturk, 2005).

Fruit quality is fundamental for the acceptance of apricot cultivars by consumers, especially due to high competition in the markets with the presence of new cultivars, other fruits and foods (Ruiz and Egea, 2008). Abbot (1999) reported that quality is a human concept that includes sensory properties (appearance, texture, taste and aroma), nutritional values, chemical compounds, mechanical and functional properties. In this sense, new apricot cultivars must be characterized by fruit quality attributes that satisfy the consumers. Sensorial properties for apricot fruits are influenced principally by the sugars, organic acids, and volatile compound contents, color, size, texture (Ruiz and Egea, 2008), firmness, attractiveness, and taste (Bassi et al., 1996; Gurrieri et al., 2001). Further, several reports on apricot showed an effect of the genetic origin and year on some pomological characteristics (Asma and Ozturk, 2005; Badenes et al., 1998; Polat and Caliskan, 2010). However, there is scarce information regarding these yearby-year variations in apricot (Ruiz and Egea, 2008).

Visual characteristics, firmness, and a balanced fruit flavor are currently the predominant traits in fresh apricot markets. However, an increased demand is being reported for fruit with high content of phytochemicals and excellent antioxidant potential. Apricot fruits are known to have a beneficial effect on human health because of antioxidants and anti-inflammatory and immune-stimulating functions that can be attributed to the content of many phenolic compounds (Madrau et al., 2009). Besides polyphenolics, apricot is also a rich source of carotenoids and vitamin $\mathrm{C}$ (Hegedũs et al., 2010). Many factors showed to influence the fruit antioxidant capacity, or quantity of individual antioxidant compounds in stone fruit species, including genotype (Drogoudi et al., 2008, Hegedũs et al., 2010), geographic region of cultivation (Dragovic-Uzelac et al., 2007), harvest year (Hegedús et al., 2010), and the dura- 
tion of the fruit development period (Dragovic-Uzelac et al., 2007).

Turkey is the main apricot producer and exporter in the world with total production of 476,132 $\mathrm{t}$ of apricots (14\% of the world production and $32 \%$ of exportation). However, Turkey's exports of fresh apricots are yet to reach the desired levels. Turkey has great potential for export of its fresh apricots because of its ecological advantages compared to France, Spain, and Greece. The most important apricot producing centers, except for Malatya in Turkey, are Erzincan, Aras valley, Mut (Mersin), Elaziğ, Kahramanmaraş, Kayseri, Hatay, and Nevşehir provinces. The Mut valley is the earliest apricot producing areas in the Europe. Thus, the first fresh apricots are sold for a high price (Ercisli, 2009). Recently, the production of fresh apricots for exports had rapidly increased mainly in the Mediterranean region of Turkey. However, fruit quality and phytochemical attributes of new Turkish and standard apricot cultivars for fresh consumption had not been evaluated in detail. The influence of cultivars and growing seasons on fruit quality and phytochemical parameters were investigated by comparing these characteristics for each cultivar over two years (2010-2011 growing seasons). This information will be useful for breeding studies to improve fruit quality and phytochemical contents in apricot cultivars.

\section{Materials and methods}

\section{Plant material}

The study was conducted at an apricot producer orchard $\left(36^{\circ} 34^{\prime} \mathrm{N}, 33^{\circ} 24^{\prime} \mathrm{E}, 150 \mathrm{~m}\right.$ elevation) in Mut, Mersin, eastern Mediterranean region of Turkey during 2010 and 2011 growing seasons. In the experiment includes 14 commercial cultivars, 'Aurora', 'Ninfa, 'Precoce de Tyrinthe', 'Antonio Errani,', 'Harcot', 'Dr Kaşka, 'Septik,' 'Bebeco, 'Roxana,' 'Super Gold', 'Alata Yıldızı, 'Çağataybey', 'Çağrıbey', and 'Şahinbey'. The cultivars 'Alata Yıldızı', 'Çağataybey',
'Çağrıbey', 'Dr Kaşka', and 'Şahinbey' were obtained from the apricot breeding program conducted in the Alata Horticultural Research Station, Mersin, Turkey (Tab. 1). All the cultivars were propagated by budding on apricot seedling rootstocks, trained by 'open center' system, and the experimental orchard was established in five replications with $5 \mathrm{~m} \times 5 \mathrm{~m}$ in 2002. A randomized-complete design was used with five single-tree replications for each cultivar. They were cultivated under standard growing conditions of irrigation, fertilization, and pest control.

\section{Fruit quality analyses}

Thirty fruits were randomly sampled from each cultivar at their fully matured stage. There were three replications, each of which consists of ten fruits. The fruit quality characteristics, i.e., weight, diameter, length, height, pit weight, flesh-pit ratio, firmness, peel color, total soluble solids (TSS), $\mathrm{pH}$, acidity, and TSS/acidity were evaluated. Fruit and pit weight $(\mathrm{g})$ were measured with a scale sensitive to $0.01 \mathrm{~g}$ (Precisa XB $2200 \mathrm{C})$. Fruit diameter (mm), length $(\mathrm{mm})$, and height $(\mathrm{mm})$ were measured by a digital caliper (Mitutoyo, 0-150 mm). Fruit diameter was measured across the fruit cheek. Fruit length was estimated as distance from the fruit stalk to the fruit apex (mucro) and fruit height was measured as length from fruit suture to the fruit back.

Firmness was evaluated with a manual penetrometer (Model Effegi FT 327, Italy) on two peeled opposite sides at the equatorial region of the apricot, using an 8-mmwide plunger. The flesh-pit ratio was calculated by dividing mean flesh weight by the mean pit weight. The TSS were determined using a hand refractometer (NOW, 0-32\% Brix) and $\mathrm{pH}$ measurements were performed using a $\mathrm{pH}$ meter (WTW InoLab pH meter). Titratable acidity (expressed as malic acid \%) was measured by titrating with $0.1 \mathrm{~N} \mathrm{NaOH}$ to $\mathrm{pH}$ 8.10. The total soluble solids/acidity ratio (TSS/Acidity) was used as an indicator of taste quality (Ledbetter et al., 2006).

Tab. 1. Pedigree and mean harvest date (2010-2011 growing seasons) of some apricot cultivars

\begin{tabular}{|c|c|c|c|}
\hline Cultivars & Origin & Pedigree & Harvest date \\
\hline 'Antonio Errani' & Italy & Selected from Reale D'lmola & 22 May \\
\hline 'Aurora' & USA & RR17-62 × NJA-13 & 6 May \\
\hline 'Bebeco' & Greece & Random seedling & 24 May \\
\hline 'Harcot' & Canada & $\begin{array}{c}(\text { Geneva } \times \text { Narmata }) \times \text { Morden } 604 \\
\times \text { NJAl }(\text { Perfection } \times \text { Phelps })\end{array}$ & 20 May \\
\hline 'Roxana' & Afghanistan & Unknown & 25 May \\
\hline 'Ninfa' & Italy & Ouaroy $\times$ P. de Tyrinthe & 2 May \\
\hline 'Super Gold' & South Africa & Peeka $\times$ Palsteyn & 18 May \\
\hline 'Precoce de Tyrinthe' & Greece & Random seedling & 12 May \\
\hline 'Alata Yıldızı' & Turkey & Sakıt $6 \times$ P.de Colomer & 25 May \\
\hline 'Çağataybey' & Turkey & Sakıt- $2 \times$ P. de Colomer & 25 May \\
\hline 'Çağrıbey' & Turkey & Sakıt- $6 \times$ P. de Colomer & 1 June \\
\hline 'Dr Kaşka' & Turkey & P. de Colomer x 07 K 11 & 28 May \\
\hline 'Septik' & Turkey & Unknown & 1 June \\
\hline 'Şahinbey' & Turkey & Sakıt- $6 \times$ J. Foulon & 1 June \\
\hline
\end{tabular}


286

Fruit peel colors were measured with a Minolta chroma meter (Chroma Meter CR-300, Minolta Co., Osaka, Japan) tristimulus color analyzer calibrated to a white porcelain reference plate. Thirty fruits of each cultivar were randomly selected and measured on two opposite peel surfaces of fruits. Color characteristics were expressed as $L^{*}$, $\mathrm{a}^{*}, C$, and $b^{\circ}$. The $\mathrm{L}$ values indicate darkness and high $\mathrm{L}^{*}$ values indicate lightness. Negative $\mathrm{a}^{*}$ values indicate green color and positive $\mathrm{a}^{*}$ values indicate red color. The $C$ value, calculated as $C=\left(\mathrm{a}^{2}+\mathrm{b}^{2}\right)^{1 / 2}$, shows color intensity. The $b^{o}$, a parameter that indicated to be effective in predicting visual color appearance, was calculated using the formula $h^{\circ}=\tan ^{-1}(\mathrm{~b} / \mathrm{a})$, where $0^{\circ}$ or $360^{\circ}=$ red-purple, $90^{\circ}=$ yellow, $180^{\circ}=$ green, and $270^{\circ}=$ blue (Francis, 1980).

A trained panel of five experts evaluated the attractiveness and taste of fruits from each cultivar. Scores from 1 to 5 were given for each cultivar regarding these parameters.

\section{Phytochemical analyses}

\section{Fruit extraction}

The apricot fruits were selected randomly to separate three replications for analysis, using $500 \mathrm{~g} /$ replication and cultivar. The sampled fruits were homogenized by blending at room temperature. The homogenate was centrifuged at $10,000 \mathrm{rpm}$ for $10 \mathrm{~min}$ at $22^{\circ} \mathrm{C}$. The supernatant was removed. The solvents were frozen and stored at $-20^{\circ} \mathrm{C}$ until analyzed for the phytochemical properties. The measured characteristics are total phenolics and antioxidant capacity followed by a single extraction procedure as described by Beccaro et al. (2006).

\section{Determination of total phenolics}

Total phenolics were determined according to the Folin-Ciocalteu reagent method according to Slinkard and Singleton (1977). In this method, $0.5 \mathrm{~g}$ of each extract was mixed with Folin-Ciocalteu's phenol reagent and water ratio of $1: 12(\mathrm{v} / \mathrm{v})$ and incubated for $8 \mathrm{~min}$ at room temperature, followed by an addition of $10 \mathrm{ml}$ of $15 \%(\mathrm{w} / \mathrm{v})$ sodium carbonate, and allowed to stand for $2 \mathrm{~h}$ at room temperature. The absorbance of each sample was measured at $760 \mathrm{~nm}$ in a spectrophotometer (Shimadzu UV1208, Japan). Gallic acid was used as a standard. Results are expressed as mg of gallic acid equivalents (GAE) 100 $\mathrm{g}^{-1}$ fresh fruit weight ( $\mathrm{fw}$ ).

\section{Determination of total antioxidant capacity}

Total antioxidant capacity was estimated by the ferricreducing antioxidant power (FRAP) assay. The FRAP was carried out as described by Pellegrini et al. (2003) and the FRAP reagent was prepared by mixing $25 \mathrm{ml}$ acetate buffer, $2.5 \mathrm{ml}$ TPTZ [2,4,6-tris(2-pyridyl)-1,3,5-triazine], and $2 \mathrm{ml}$ ferric chloride. Then, a 9-ml aliquot of FRAP reagent was combined with $9 \mathrm{ml}$ of methanolic fruit extract. The samples were incubated at $37^{\circ} \mathrm{C}$ for $30 \mathrm{~min}$, and final absorbance at $593 \mathrm{~nm}$ was measured spectrophotometrically (Shimadzu UV-1208, Japan). $\mathrm{FeSO}_{4} \times 7 \mathrm{H}_{2} \mathrm{O}(10-100 \mu \mathrm{M})$ was used as a standard. Total antioxidant capacity (TAC) values were expressed as $\mathrm{Fe}^{2+}$ equivalents. $\mathrm{mmol} \mathrm{kg}{ }^{-1} \mathrm{fw}$.

\section{Sugar analyses}

Analyses of sugars were performed as per the method described by Camara et al. (1996). Apricot fruit homogenates of $10 \mathrm{~g}$, were diluted with distilled water $(40 \mathrm{ml})$ to prepare solution for detection of sugar composition. These were centrifuged at 10,000 rpm for $10 \mathrm{~min}$, and the supernatants were filtered through Whatman No. 42 filter paper. Aliquots of two milliliters of filtered homogenate per tube were then combined with $6 \mathrm{ml}$ of acetonitrile. These solutions were filtered through $0.45 \mathrm{~mm}$ membrane filters (Millipore, USA) prior to high-performance liquid chromatography (HPLC) analysis. All the samples and standards were injected three times to HPLC. EC 250/4 Nucleosil C18 carbohydrate column $(250 \mathrm{~mm}-4.0 \mathrm{~mm}$ i.d.) was used (Macherey-Nagel, USA). The HPLC analyses were conducted using a Shimadzu HPLC system, with an LC-10AT pump and RID-10A detector (Shimadzu, Japan). The elution solvent used contained $80 \%$ acetonitrile and $20 \%$ deionized water. The column was operated at $30^{\circ} \mathrm{C}$ with a flow rate of $1.8 \mathrm{ml} / \mathrm{min}$.

\section{Data analysis}

The data were analyzed using SAS software and procedures (SAS Institute Inc., North Carolina, USA). Differences between cultivars and years as well as cultivaryear interactions were determined by analysis of variance (ANOVA). ANOVA tables were constructed using Tukey's Honestly Significant Difference (HSD) method at $p<$ 0.05 . Restricted maximum likelihood (REML) was used to estimate variance components. Pearson's correlation coefficients and their significance levels were calculated on a cultivar-mean basis using PROC CORR.

\section{Results and discussion}

\section{Harvest date}

Early production is one of the most important reasons for growing fresh apricot in the Mediterranean region of Turkey. All cultivars used were harvested between May and June. The earliest apricot cultivars were 'Ninfa' (2 May), 'Aurora' (6 May), and 'Precoce de Tyrinthe' (12 May). In this study, many cultivars were harvested in lateMay. The early-ripening cultivars were of European (such as, 'Antonio Errani', 'Bebeco', and 'Ninfa') and America ('Aurora' and 'Harcot'). While the new Turkish cultivars 'Alata Yıldızi,' 'Çağataybey', and 'Dr. Kaşka' were harvested in late May, 'Çağribey' and 'Şahinbey' were harvested in early June. In the previous studies, the harvest data for apricot cultivars were in the range of 14 May-26 June in Spain (Ruiz and Egea, 2008), 11 June-10 September in Hungary (Hegedũs et al., 2010), 26 May-25 June in Italy (Lo Bianco et al., 2010). In addition, 'Precoce de Tyrinthe' grown in Mut (Turkey) was harvested 15-20 days earlier than in 
Spain (Badenes et al., 1998) and France (Radi et al., 1997). The Ninfa in Mut Valley, Turkey, was harvested about 25 days before the one in Italy (Lo Bianco et al., 2010). Ercisli (2009) reported that Mut Valley of Mediterranean region in Turkey is the earliest apricot producing area in the Europe. This result could be due to climatical conditions in Mut Valley, where the climate is semi-arid, having hot summers and cold winters. This region had high day-night temperature changes from February to May $\left(>15^{\circ} \mathrm{C}\right)$ and maximum temperatures were $>28^{\circ} \mathrm{C}$ in April and May (Fig.1). Therefore, the apricot cultivars could be early fulfilling degree-day thresholds from full-bloom to harvest in the Mut Valley conditions. Ruml et al. (2010) indicated that the effect of growing degree-day thresholds on harvest time of apricots is very important for each apricot-producing region. The authors also reported that daily maximum temperatures were the most influential temperature variable for the ripening time of apricots.

\section{Fruit quality attributes}

The evaluation of fresh fruit quality in new apricot cultivars requires knowledge of the quality characteristics of reference cultivars, or those that would be available during the same maturity season. The reference cultivars should be grown with similar orchard conditions and cultural practices. The harvest maturity of different apricot cultivars must also be very similar to have valid comparisons (Ledbetter, 2008). Therefore, the authors compared the standard apricot cultivars with new Turkish apricot cultivars in similar conditions. The results of variance and variance-component analyses showed that cultivar and growing season were the main factors $(p<0.05)$ affecting

Tab. 2. Effect of cultivar and season on fruit quality properties of some apricot cultivars

\begin{tabular}{|c|c|c|c|c|c|c|c|c|c|c|c|}
\hline Variable & $\begin{array}{l}\text { Fruit } \\
\text { weight } \\
(\mathrm{g})\end{array}$ & $\begin{array}{c}\text { Fruit } \\
\text { diameter } \\
(\mathrm{mm})\end{array}$ & $\begin{array}{c}\text { Fruit } \\
\text { length } \\
(\mathrm{mm})\end{array}$ & $\begin{array}{l}\text { Fruit } \\
\text { height } \\
(\mathrm{mm})\end{array}$ & $\begin{array}{c}\text { Pit } \\
\text { weight } \\
(\mathrm{g})\end{array}$ & $\begin{array}{l}\text { Flesh- } \\
\text { pit ratio }\end{array}$ & $\begin{array}{l}\text { Firmness } \\
\left(\mathrm{kg} / \mathrm{cm}^{2}\right)\end{array}$ & $\begin{array}{l}\text { TSS } \\
(\%)\end{array}$ & $\mathrm{pH}$ & $\begin{array}{c}\text { Acidity } \\
(\%)\end{array}$ & $\begin{array}{c}\text { TSS/ } \\
\text { Acidity }\end{array}$ \\
\hline \multicolumn{12}{|c|}{ Cultivar } \\
\hline 'Antonio Errani' & $78.4 a^{a}$ & $49.6 \mathrm{a}$ & $50.8 \mathrm{a}$ & $54.0 \mathrm{a}$ & $7.3 \mathrm{a}$ & $10.3 \mathrm{c}$ & $2.4 \mathrm{e}$ & $11.6 \mathrm{c}$ & $3.53 c$ & $1.7 \mathrm{~cd}$ & $7.6 \mathrm{c}$ \\
\hline 'Aurora' & $36.7 \mathrm{gh}$ & $37.2 \mathrm{~g}$ & 39.3hi & $42.5 \mathrm{gh}$ & $1.5 \mathrm{~d}$ & $26.0 \mathrm{a}$ & $1.1 \mathrm{f}$ & $11.5 \mathrm{c}$ & $3.36 \mathrm{f}$ & 1.6de & $7.0 \mathrm{~cd}$ \\
\hline 'Bebeco' & $56.9 \mathrm{c}$ & $44.2 \mathrm{bc}$ & $47.8 \mathrm{bc}$ & $46.5 \mathrm{de}$ & $2.5 \mathrm{~cd}$ & $22.8 \mathrm{ab}$ & $3.8 \mathrm{bc}$ & $11.6 \mathrm{c}$ & $3.50 \mathrm{~cd}$ & $1.4 \mathrm{gh}$ & $8.9 \mathrm{~b}$ \\
\hline 'Harcot' & $51.3 \mathrm{cde}$ & $42.8 \mathrm{~cd}$ & 45.4cde & $48.1 \mathrm{bcd}$ & $2.9 \mathrm{bcd}$ & 17.1abc & 3.0de & $10.7 \mathrm{cde}$ & $3.40 \mathrm{ef}$ & $1.9 \mathrm{~b}$ & $5.5 \mathrm{fg}$ \\
\hline 'Roxana' & $60.3 c$ & $45.1 \mathrm{~b}$ & $47.6 \mathrm{bc}$ & $52.1 \mathrm{a}$ & $3.7 \mathrm{bc}$ & $15.3 \mathrm{bc}$ & $4.8 \mathrm{a}$ & $11.4 \mathrm{c}$ & $3.20 \mathrm{gh}$ & $2.3 \mathrm{a}$ & $5.0 \mathrm{~g}$ \\
\hline 'Ninfa' & $26.7 \mathrm{~h}$ & $35.0 \mathrm{~g}$ & $36.9 \mathrm{i}$ & $38.8 \mathrm{i}$ & $2.6 \mathrm{bcd}$ & $10.4 \mathrm{c}$ & $1.3 \mathrm{f}$ & $10.6 \mathrm{~cd}$ & $3.74 \mathrm{a}$ & $1.2 \mathrm{~h}$ & $8.9 \mathrm{~b}$ \\
\hline 'Super Gold' & $49.8 \mathrm{c}-\mathrm{f}$ & $42.3 \mathrm{cde}$ & $44.2 \mathrm{def}$ & $44.5 \mathrm{fg}$ & $3.5 b c$ & $17.3 \mathrm{abc}$ & $1.1 f$ & $13.4 b$ & $3.55 \mathrm{c}$ & $1.6 \mathrm{ef}$ & $8.6 \mathrm{~b}$ \\
\hline 'Precoce de Tyrinthe' & $55.3 \mathrm{~cd}$ & $44.3 \mathrm{bc}$ & $46.5 \mathrm{bcd}$ & $47.5 \mathrm{~cd}$ & $3.2 \mathrm{bcd}$ & $17.2 \mathrm{abc}$ & $3.1 \mathrm{cde}$ & $9.8 \mathrm{f}$ & 3.44 def & $1.5 \mathrm{efg}$ & $5.8 \mathrm{efg}$ \\
\hline 'Alata Yıldızi' & $61.0 \mathrm{bc}$ & $45.1 \mathrm{~b}$ & $48.8 \mathrm{ab}$ & $49.2 \mathrm{bc}$ & $3.7 \mathrm{bc}$ & $15.9 \mathrm{bc}$ & $4.0 \mathrm{~b}$ & 10.6cde & $3.26 \mathrm{~g}$ & $1.7 \mathrm{~cd}$ & $6.2 \mathrm{def}$ \\
\hline 'Çağataybey' & $44.6 \mathrm{~d}-\mathrm{g}$ & 40.6def & $42.8 \mathrm{fg}$ & $45.2 \mathrm{ef}$ & $2.8 \mathrm{bcd}$ & $14.8 b c$ & $3.9 \mathrm{~b}$ & $14.6 \mathrm{a}$ & $3.54 \mathrm{c}$ & $1.4 \mathrm{fgh}$ & $10.4 \mathrm{a}$ \\
\hline 'Çağribey' & $39.7 \mathrm{efg}$ & 40.1ef & 43.4efg & $41.0 \mathrm{~h}$ & $3.8 \mathrm{bc}$ & $11.1 \mathrm{c}$ & $4.3 \mathrm{ab}$ & $10.9 \mathrm{~cd}$ & $3.64 \mathrm{~b}$ & $1.3 \mathrm{~h}$ & $8.8 \mathrm{~b}$ \\
\hline 'Dr Kaşka' & $34.6 \mathrm{gh}$ & $36.3 \mathrm{~g}$ & $39.7 \mathrm{~h}$ & $42.7 \mathrm{gh}$ & $2.4 \mathrm{~cd}$ & $15.0 \mathrm{bc}$ & $3.7 \mathrm{bcd}$ & $9.7 \mathrm{f}$ & $3.15 \mathrm{~h}$ & $2.4 \mathrm{a}$ & $3.9 \mathrm{~h}$ \\
\hline 'Septik' & $38.2 \mathrm{fgh}$ & $40.0 \mathrm{f}$ & $41.6 \mathrm{gh}$ & $37.8 \mathrm{i}$ & $3.8 \mathrm{bc}$ & $9.2 \mathrm{c}$ & $2.9 \mathrm{e}$ & $10.3 \mathrm{de}$ & $3.38 \mathrm{f}$ & $1.8 \mathrm{bc}$ & $5.8 \mathrm{efg}$ \\
\hline 'Şahinbey' & $72.6 \mathrm{ab}$ & $49.9 \mathrm{a}$ & $50.5 \mathrm{a}$ & $49.9 \mathrm{~b}$ & $4.3 \mathrm{~b}$ & $15.9 \mathrm{bc}$ & 3.0de & $9.6 f$ & $3.48 \mathrm{cde}$ & 1.6de & $6.4 \mathrm{de}$ \\
\hline Mean & 50.4 & 42.3 & 44.7 & 45.7 & 3.4 & 15.6 & 3.0 & 11.0 & 3.4 & 1.7 & 7.1 \\
\hline \multicolumn{12}{|c|}{ Season } \\
\hline 2010 & $52.4 a$ & 42.5 & 44.9 & $46.5 \mathrm{a}$ & $3.7 \mathrm{a}$ & $17.0 \mathrm{a}$ & $3.3 \mathrm{a}$ & $11.2 \mathrm{a}$ & $3.5 \mathrm{a}$ & 1.7 & $7.2 \mathrm{a}$ \\
\hline 2011 & $48.5 b$ & 42.1 & 44.5 & $44.9 \mathrm{~b}$ & $3.1 \mathrm{~b}$ & $14.2 \mathrm{~b}$ & $2.7 \mathrm{~b}$ & $10.7 b$ & $3.4 \mathrm{~b}$ & 1.8 & $6.8 \mathrm{~b}$ \\
\hline $\mathrm{HSD}_{\text {Cultivar (C) }}$ & 12.11 & 2.3 & 2.5 & 2.1 & 1.7 & 9.6 & 0.8 & 1.1 & 4.95 & 0.16 & 0.9 \\
\hline $\mathrm{HSD}_{\text {Scasonr }(\mathrm{S})}$ & 2.6 & ns & ns & 0.5 & 0.4 & 2.1 & 0.2 & 0.2 & 0.02 & 0.04 & 0.2 \\
\hline $\mathrm{HSD}_{\mathrm{CxS}}$ & 16.5 & 5.9 & 5.6 & 5.0 & 1.4 & 6.9 & 1.9 & 2.2 & 0.32 & 0.89 & 1.0 \\
\hline \multicolumn{12}{|c|}{ ANOVA (mean square) } \\
\hline Cultivar (C) & $1315.5^{* *}$ & $121.4^{* *}$ & $111.1^{* *}$ & $140.3^{* *}$ & $10.6^{* *}$ & $131.7^{* *}$ & $8.4^{* *}$ & $16.0^{* *}$ & $0.16^{* *}$ & $0.69^{* *}$ & $20.7^{* *}$ \\
\hline Season $(S)$ & $330.6^{*}$ & $3.6 n s$ & 3.2 & $57.0^{* *}$ & $9.9^{*}$ & $169.3^{*}$ & $6.9^{* *}$ & $6.4^{* *}$ & $0.41^{* *}$ & $0.05 \mathrm{~ns}$ & $2.10^{*}$ \\
\hline $\mathrm{C} \times \mathrm{S}$ & $159.6^{* *}$ & $20.4^{* *}$ & $18.5^{* *}$ & $14.8^{* *}$ & $1 . \operatorname{lns}$ & $28.5 \mathrm{~ns}$ & $2.2^{* *}$ & $2.8^{* *}$ & $0.06^{* *}$ & $0.46^{* *}$ & $14.8^{* *}$ \\
\hline Error & 35.8 & 1.29 & 1.52 & 1.09 & 0.73 & 22.4 & 0.13 & 0.27 & 0.01 & 0.01 & 0.19 \\
\hline \multicolumn{12}{|c|}{ Variance component distributions (\%) } \\
\hline Cultivar (C) & 70.4 & 69.8 & 69.4 & 75.8 & 59.4 & 44.5 & 52.3 & 64.6 & 35.6 & 20.87 & 17.2 \\
\hline Season $(S)$ & 1.5 & 0.0 & 0.0 & 3.64 & 7.8 & 6.6 & 5.6 & 2.5 & 17.9 & 15.0 & 20.5 \\
\hline $\mathrm{C} \times \mathrm{S}$ & 15.1 & 24.8 & 23.8 & 16.6 & 4.8 & 4.1 & 35.0 & 24.7 & 43.1 & 55.6 & 59.0 \\
\hline Error & 13.1 & 5.4 & 6.8 & 3.95 & 27.9 & 34.8 & 7.0 & 8.1 & 3.3 & 3.52 & 3.2 \\
\hline
\end{tabular}

aDifferent letters within columns indicate significant differences by Tukey's HSD (Honestly Significant Difference) test at $p<0.05$. TSS: total soluble solids, ns: Non-significant 


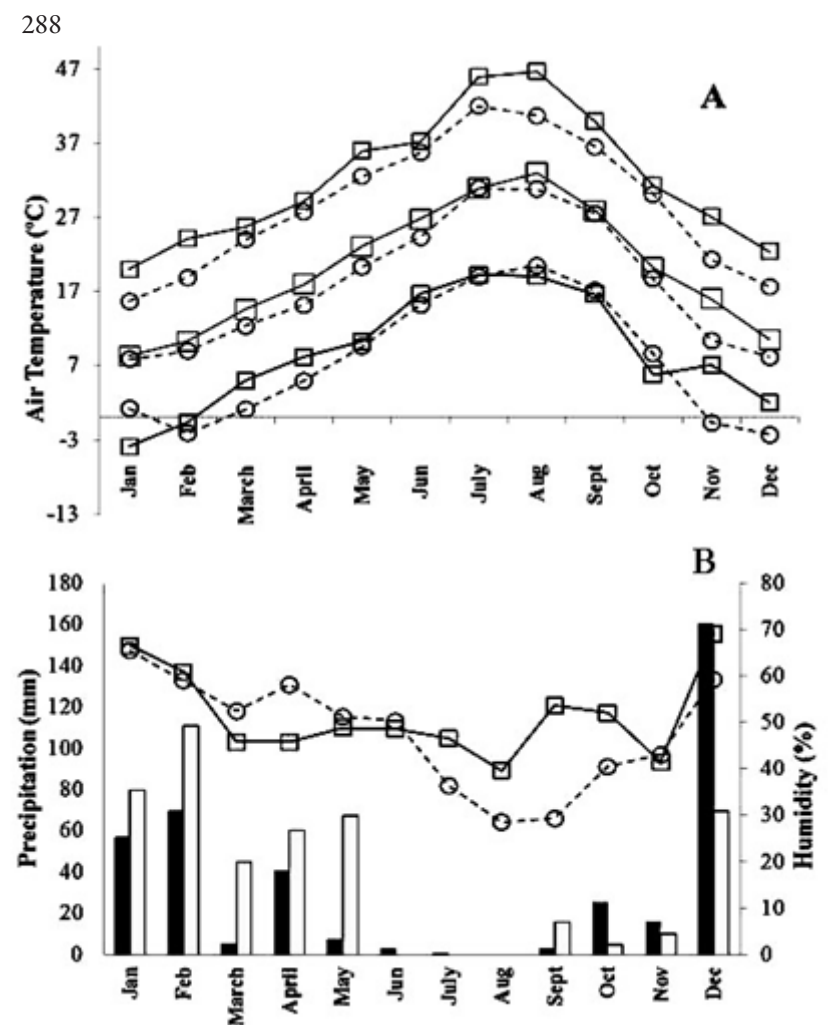

Fig. 1. Meteorological data for Mut Mersin, in the eastern Mediterranean region of Turkey. (A) Minimum, maximum, and mean air temperatures in 2010 ( $\square$ ) and 2011 (O) (B) precipitation level in 2010 (black columns) and 2011 (gray columns), and mean humidity in 2010 ( $\square$ ) and 2011 (O)

fruit quality characteristics of apricots (Tab. 2). Genotypic effect, explained for the highest proportion of variation on fruit quality characteristics, the mean of two years was changed between $17.2 \%$ (TSS/Acidity) and 75.8\% (fruit height). The mean fruit weight of the apricot cultivars was ranged from $26.7 \mathrm{~g}$ ('Ninfa') to $78.4 \mathrm{~g}$ ('Antonio Errani'). The fruit size is one of the most important fruit quality traits for fresh apricots. Regarding the 'Apricot Descriptor' (IPGRI and CEC, 1984), the fruit weight for 'Antonio Errani' and 'Şahinbey' were very large (>70 g), 'Alata Yıldızı' was large (61-70 g), 'Precoce de Tyrinthe', and 'Bebeco' and 'Roxana' were medium-to-large (56-60 g) in Mut ecological conditions. The other cultivars were medium ('Super Gold' and 'Harcot'), small/medium ('Çağataybey'), and small ('Septik', 'Dr. Kaşka,' 'Çağrıbey', 'Ninfa,' and 'Aurora'). The fruit diameter, length, and height for 'Antonio Errani' and 'Şahinbey' were very high (49.6, 50.8, and 54.0 $\mathrm{mm} ; 49.9,50.5$, and $49.9 \mathrm{~mm}$, respectively). The 'Ninfa' had the lowest fruit-size values. The previous studies on apricot also reported a high variability among apricot cultivars regarding fruit-size traits (Badenes et al., 1998; Ruiz and Egea, 2008). Generally, the fruit-weight values of Turkish apricot cultivars, except for 'Alata Yıldız' and 'Şahinbey' were lower $(<50 \mathrm{~g})$ than those of other apricot genotypes originating from the European ecogeographical group reported in literature (Milošević et al., 2010; Ruiz and Egea, 2008).

These results were in agreement with those that of Asma and Ozturk (2005), who reported that Irano-Caucasian ecogeographical group apricots is composed of lower fruit weights. Yearly variations were statistically significant, except for fruit diameter, fruit length, and acidity. This variation in fruit weights can be attributed to specific gravity of apricot fruits. The pit weight and flesh-pit ratio were higher in 2010 growing-season than in 2011.

The pit weight was the highest for 'Antonio Errani' (7.3 g) and 'Şahinbey' ( $4.3 \mathrm{~g})$ out of fourteen cultivars whereas flesh-pit ratio was the lowest for 'Septik' (9.2), 'Antonio Errani' (10.3), and 'Ninfa' (10.4). High flesh-pit ratio is a desired characteristic for fresh apricots. Cultivar $\times$ Season interaction was not significant for the pit weight and fleshpit ratio variables. The fruit firmness values were higher than $1 \mathrm{~kg} / \mathrm{cm}^{2}$ for all apricot cultivars. All the cultivars, except for 'Roxana' $\left(4.8 \mathrm{~kg} / \mathrm{cm}^{2}\right)$ and 'Çağribey' $\left.4.3 \mathrm{~kg} / \mathrm{cm}^{2}\right)$ showed values between 1 and $3 \mathrm{~kg} / \mathrm{cm}^{2}$, suitable for fresh consumption (Ruiz and Egea, 2008). A significant yearly variance distribution in fruit firmness was found moremarked depending on the apricot cultivars (52.3\%).

The TSS content is an important quality attribute, influencing notably the fruit taste. The levels of TSS in this study ranged from $9.6 \%$ ('Şahinbey') to $14.6 \%$ ('Çağataybey') with a mean of $11 \%$, which is greater than the minimum (10\%) established by the EU (European Union) to market apricots (R-CE No.112/2001). Kader (1999) considered the mean values of TSS over $10 \%$ as the minimum value for consumer acceptance for apricots, which is the case in our cultivars. The TSS contents of new Turkish apricot cultivars 'Çağataybey', 'Çağrıbey', and 'Alata Yildizi' were $>10 \%$. The pedigree of the new cultivars is included 'Sakıt' apricot group, which is characterized by an excellent fruit taste (level of TSS $>20 \%$ ) and quality (Ayanoglu et al., 1995). The TSS contents of apricots were mainly affected by cultivar $(64.6 \%)$. The $\mathrm{pH}$, acidity, and TSS/acidity were significantly affected by cultivar $\times$ season interaction (43.1\%, 55.6\%, and 59\%, respectively). The highest $\mathrm{pH}$ and lowest acidity were found for 'Ninfa' (3.74 and $1.2 \%$, respectively). These acidity values were in agreement with previous studies in apricot (Hegedũs et al., 2010). Further, the cultivar 'Roxana' and 'Dr. Kaşka' (2.3\% and $2.4 \%$, respectively) had the highest acidity. In our study, no yearly variation was determined in terms of acidity. Similarly, Ruiz and Egea (2008) reported that yearly variation in acidity was not observed. This can be due to the fruit maturity stage at the harvest date and climatic conditions before harvesting. In addition, 'Precoce de Tyrinthe' grown in the Mut Valley, Turkey, was low acidic than Avignon (France) (Gurrieri et al., 2001) and Metaponto (Italy) (Leccese et al., 2008). Besides, Lo Bianco et al. (2010) indicated that early and late-ripening apricot cultivars had the highest acidity contents. 'Roxana' and 'Dr. Kaşka' cultivars whose harvest dates were late-May in 
the Mut Valley ecological conditions showed the highest acidity values. The average acidity (1.7\%) of cultivars under the Mut Valley conditions at commercial harvest was well below the maximum level (4.4\%) for acceptance by panel test and within the range for evaluating a high taste score (Audergon et al., 1991).

The maturity index (MI; TSS/acidity) can be a good indicator for good fruit taste and can be a descriptive parameter in selecting cultivars for specific uses of fruit species (Polat and Caliskan, 2008). However, the consumers acceptance of the cultivars with acidity $>0.9 \%$ and TSS $<12 \%$, was controlled by the interaction between acidity and TSS, rather than TSS alone (Crisosto et al., 2004). The MI values were the lowest in 'Dr. Kaşka' (3.9) and the highest in 'Çağataybey' (10.4). Asma and Ozturk (2005) reported that Turkish apricot cultivars were highest levels of TSS and the lowest acidity. Therefore, 'Çağataybey' cultivar which is hybrid of 'Sakit 2 x P. de Colomer' was similar to Sakıt 2 with high TSS and low acidity. Similarly, some researchers reported that higher TSS and lower TA in Asian cultivars compared with California adapted apricots (Ledbetter $e t$ al., 2006). The earliest cultivars 'Ninfa' and 'Aurora' had above-average MI values (>7.05). In addition, the values of 'Çağataybey,' 'Bebeco', 'Çağrıbey', 'Super Gold', and 'Antonio Errani' were above-average MI.

Sensory analysis of attractiveness and taste were shown in Tab. 3. The application of sensory analysis using a panel of selected and trained tasters is a reliable and effective method for the evaluation of the organoleptic quality of apricots (Egea et al., 2006). Most of the apricot cultivars showed good characteristics regarding attractiveness and taste. The cultivar 'Çağataybey', 'Super Gold', 'Aurora', and 'Ninfa' had highest attractiveness and taste values. The lowest panelist values were found for 'Antonio Errani' and

Tab. 3. Sensorial characteristics of some apricot cultivars

\begin{tabular}{ccccc}
\hline Cultivar & Attractiveness & Taste & $\begin{array}{c}\text { Blush } \\
\text { Color } \\
\text { Ratio, } \%\end{array}$ & $\begin{array}{c}\text { Blush } \\
\text { Color }\end{array}$ \\
\hline 'Antonio Errani' & 2.6 & 1.8 & 10 & Red \\
\hline 'Aurora' & 4.0 & 4.0 & 10 & Red \\
\hline 'Bebeco' & 2.8 & 3.0 & 10 & Red \\
\hline 'Harcot' & 3.4 & 2.4 & 5 & Rose \\
\hline 'Roxana' & 3.4 & 3.0 & 25 & Red \\
\hline 'Ninfa' & 4.2 & 3.6 & 30 & Orange \\
\hline 'Super Gold' & 4.4 & 4.2 & 10 & Orange \\
\hline 'Precoce de Tyrinthe' & 4.0 & 2.2 & 5 & Orange \\
\hline 'Alata Yıldız' & 3.0 & 2.6 & 5 & Red \\
\hline 'Çağataybey' & 4.6 & 4.8 & 60 & Red \\
\hline 'Çağribey' & 3.8 & 3.0 & 10 & Red \\
\hline 'Dr Kaşka' & 2.8 & 1.8 & 5 & Orange \\
\hline 'Septik' & 3.4 & 3.0 & 5 & Orange \\
\hline 'Şahinbey' & 3.6 & 3.4 & 10 & Orange \\
\hline
\end{tabular}

'Dr. Kaşka'. The results agreed with the TSS and MI values of the cultivars.

The percentage of blush color on the fruit peel varied depending on the cultivar. 'Çağataybey,' 'Roxana', and 'Ninfa' showed more than $25 \%$ of blush color on the fruit peels that influences positively their attractiveness.

The results were similar to those obtained by Ruiz and Egea (2008), who reported that blush color on fruit peel are changed based on apricot genotypes. In apricots, however, better peel coloration (towards orange/red) seems to be associated with increased acidity, but not increased sugar content and selecting towards orange/red peel color may incur loss of flavor and taste (Lo Bianco et al., 2010). Conversely, 'Çağataybey' cultivar had the highest blush color on fruit peel and richest TSS content. Therefore, it can indicated that Sakıt 2 cultivar with high TSS $(>20 \%)$ and $40-60 \%$ red blush is very important as a donor plant for breeding studies.

Tab. 4. Effect of cultivar and season on fruit peel color characteristics of some apricot cultivars

\begin{tabular}{|c|c|c|c|c|c|}
\hline Variable & $\mathrm{L}^{*}$ & $\mathrm{a}^{*}$ & $b^{*}$ & $C$ & $b^{\circ}$ \\
\hline \multicolumn{6}{|c|}{ Cultivar } \\
\hline 'Antonio Errani' & $68.5 b c^{a}$ & $5.2 \mathrm{bcd}$ & $48.4 \mathrm{abc}$ & $49.3 \mathrm{ab}$ & $83.5 \mathrm{bcd}$ \\
\hline 'Aurora' & $57.8 \mathrm{f}$ & $6.8 \mathrm{bc}$ & $39.9 \mathrm{ef}$ & $40.6 f$ & $80.3 \mathrm{~d}$ \\
\hline 'Bebeco' & $69.5 \mathrm{bc}$ & $-3.1 \mathrm{ef}$ & $47.3 \mathrm{bc}$ & $47.9 \mathrm{bcd}$ & $93.4 \mathrm{a}$ \\
\hline 'Harcot' & $70.0 \mathrm{abc}$ & $3.4 \mathrm{~d}$ & $48.8 \mathrm{ab}$ & $49.3 \mathrm{ab}$ & $85.5 b c$ \\
\hline 'Roxana' & $62.7 \mathrm{de}$ & $3.6 \mathrm{~cd}$ & $43.3 \mathrm{de}$ & 45.1de & $84.5 \mathrm{bcd}$ \\
\hline 'Ninfa' & $69.5 \mathrm{bc}$ & $7.6 \mathrm{~b}$ & $49.4 \mathrm{ab}$ & $50.4 \mathrm{ab}$ & $80.3 \mathrm{~d}$ \\
\hline 'Super Gold' & 67.1bcd & $7.3 \mathrm{~b}$ & $51.7 \mathrm{a}$ & $52.4 \mathrm{a}$ & $81.7 \mathrm{~cd}$ \\
\hline 'Precoce de Tyrinthe' & $74.2 \mathrm{a}$ & $2.3 \mathrm{~d}$ & $49.5 \mathrm{ab}$ & $49.2 \mathrm{abc}$ & $86.4 b$ \\
\hline 'Alata Yıldızı' & $71.6 \mathrm{ab}$ & $-5.5 f$ & $47.9 \mathrm{abc}$ & $48.4 \mathrm{bcd}$ & $96.6 a$ \\
\hline 'Çağataybey' & $58.3 \mathrm{ef}$ & $16.9 \mathrm{a}$ & $36.6 f$ & $42.2 \mathrm{ef}$ & 64.1e \\
\hline 'Çağrıbey' & $66.6 \mathrm{~cd}$ & $-2.8 \mathrm{ef}$ & $47.1 \mathrm{bcd}$ & $45.5 \mathrm{cde}$ & $92.7 \mathrm{a}$ \\
\hline 'Dr Kaşka' & $70.0 \mathrm{abc}$ & $-1.5 \mathrm{e}$ & $44.9 \mathrm{~cd}$ & $45.1 \mathrm{de}$ & $96.1 \mathrm{a}$ \\
\hline 'Septik' & $66.1 \mathrm{~cd}$ & $-3.1 \mathrm{ef}$ & $47.9 \mathrm{~cd}$ & $45.6 \mathrm{cde}$ & $93.4 \mathrm{a}$ \\
\hline 'Şahinbey' & $70.6 \mathrm{abc}$ & $-4.5 \mathrm{ef}$ & $47.7 \mathrm{bc}$ & $49.0 \mathrm{abc}$ & $93.9 \mathrm{a}$ \\
\hline Mean & 66.5 & 2.37 & 45.7 & 46.6 & 85.2 \\
\hline \multicolumn{6}{|c|}{ Season } \\
\hline 2010 & $67.8 \mathrm{a}$ & $3.2 \mathrm{a}$ & $46.7 \mathrm{a}$ & $47.7 \mathrm{a}$ & $87.4 \mathrm{a}$ \\
\hline 2011 & $66.8 \mathrm{~b}$ & $1.3 \mathrm{~b}$ & $45.8 \mathrm{~b}$ & $46.6 b$ & $85.2 b$ \\
\hline $\mathrm{HSD}_{\text {Cultivar (C) }}$ & 4.5 & 3.3 & 3.9 & 3.7 & 4.6 \\
\hline $\mathrm{HSD}_{\text {Seasonr (S) }}$ & 0.9 & 0.7 & 0.8 & 0.8 & 1.0 \\
\hline $\mathrm{HSD}_{\mathrm{CxS}}$ & 1.9 & 5.7 & 3.8 & 3.8 & 7.5 \\
\hline \multicolumn{6}{|c|}{ ANOVA (mean square) } \\
\hline Cultivar (C) & $137.1^{* *}$ & $232.3^{* *}$ & $96.4^{* *}$ & $63.9^{* *}$ & $431.9^{* *}$ \\
\hline Season $(S)$ & $23.4^{*}$ & $72.9^{* *}$ & $15.5^{*}$ & $23.5^{*}$ & $100.9^{* *}$ \\
\hline $\mathrm{C} \times \mathrm{S}$ & $2.3 \mathrm{~ns}$ & $19.0^{* *}$ & $8.5^{*}$ & $8.4^{*}$ & $33.0^{* *}$ \\
\hline Error & 5.0 & 2.7 & 3.7 & 3.3 & 5.2 \\
\hline \multicolumn{6}{|c|}{ Variance component distributions (\%) } \\
\hline Cultivar (C) & 81.7 & 79.1 & 73.1 & 63.0 & 80.5 \\
\hline Season $(S)$ & 1.7 & 2.9 & 0.8 & 2.4 & 2.0 \\
\hline $\mathrm{C} \times \mathrm{S}$ & 10.7 & 12.1 & 7.7 & 11.2 & 11.2 \\
\hline Error & 6.6 & 6.0 & 18.4 & 6.4 & 6.3 \\
\hline
\end{tabular}

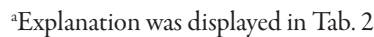


290

\section{Fruit peel color measurements}

The levels of fruit peel color in apricot cultivars were significantly different depended on cultivars, growing season, and cultivar $\times$ season (Tab. 4). Cultivars had the main effect $(p<0.01)$ on fruit peel color traits and its effects were ranged from $63.0 \%(C)$ and $81.7 \%\left(\mathrm{~L}^{*}\right)$. The fruit color is an important indicator for fruit ripeness and harvest date of some fruits. Besides, the cultivars with different fruit peel color can be satisfying various consumer preferences (Çalişkan and Polat, 2011). Generally, the $\mathrm{L}^{*}, C$, and $h^{\circ}$ values are commonly used for objective color description in apricot (Ruiz et al., 2005). The decrease in $\mathrm{L}^{*}$ and $b^{\circ}$ values shows the orange peel color, whereas the increase of these values corresponds to lighting of the peel color. The fruit $\mathrm{L}^{*}$ value was the lightest for 'Precoce de Tyrinthe' (74.2). The result was similar to the data obtained by Durmaz et al. (2010), who reported that early ripening apricot cultivars have higher $L^{*}$ values. The $a^{*}$ value indicating red color, was highest for 'Çağataybey' (16.9), whereas it was negative (yellow-green color) for 'Alata Yıldızı' (-5.5). 'Super Gold' and 'Ninfa' had the highest b* values (51.7 and 49.4) showing yellow color. These results were in agreement with those of Lo Bianco et al. (2010) reporting that 'Ninfa' has light peel coloration.

The fruit peel color $C$ and $b^{\circ}$ values were lowest for 'Aurora' ( 40.6 and 80.3 , respectively) and 'Çağataybey' ( 42.2 and 64.1, respectively). The increase in $C$ value creates the orange color (Hegedũs et al., 2010). The lowest $C$ values were obtained from Turkish apricot cultivars. The data were in agreement with Asma and Ozturk (2005), who indicated that generally, Turkish apricot cultivar having yellow peel ground color.

Some researchers indicated that $b^{o}$ value is a suitable character for estimating carotenoid levels of fruit species (Ruiz et al., 2005). 'Aurora' and 'Çağataybey' cultivars with the lowest $b^{\circ}$ values can be regarded as the cultivars, with the richest carotenoid levels, whereas 'Alata Yildizi', 'Dr Kaşka,' 'Çağrıbey', 'Septik', and 'Şahinbey' with the highest $h^{\circ}$ values are likely to be the lowest carotenoid levels. Hegedũs et al. (2010) reported that 'Aurora' having low $b^{\circ}$ values is likely to be the richest sources of carotenoids.

The effects of growing season on fruit peel color was significant, but its contributions to total variation was minor (Tab. 4). The $\mathrm{a}^{*}$ and $C$ values for fruit peel color had the highest effects (2.9\% and $2.4 \%$, respectively). The highest lightness for red and yellow fruit peel color values (87.4) of the apricot were found in 2010. This color density can be related with temperature reached a level of 36 ${ }^{\circ} \mathrm{C}$, and a minor precipitation in maturity stage in May, 2010 (Fig. 1). In contrast to our results, Ruiz and Egea (2008) reported that yearly variation was not detected on apricot peel color. Previous studies also reported that fruit color can vary from year to year depending on sunlight and temperature. In addition, temperature has a major influence on anthocyanin synthesis for coloring in fruit species (Mori et al., 2007).

\section{Phytochemical and sugar attributes}

The level of TP and TAC showed considerable diversity among the cultivars analyzed (Tab. 5). The ANOVA and REML analyses showed that cultivar was the major factor affecting TP and TAC contents (68.1 and 70.5\%, respectively) as it was reported for several fruit species (Drogoudi et al., 2008; Hegedũs et al., 2010; Çalişkan and Polat, 2011).

The apricot cultivars had high levels of TP and TAC. The levels of TP ranged between 14.4 and $177.1 \mathrm{mg} \mathrm{GAE}$ $100 \mathrm{~g}^{-1} \mathrm{fw}$, with a mean value of $64.4 \mathrm{mg}$ GAE $100 \mathrm{~g}^{-1} \mathrm{fw}$; the levels of TAC ranged between 2.3 and $12.3 \mathrm{mmol} \mathrm{Fe}^{2+}$ $\mathrm{kg}^{-1} \mathrm{fw}$, with mean value of $7.1 \mathrm{mmol} \mathrm{Fe} \mathrm{kg}^{2+} \mathrm{fw}$. 'Alata Ylldizi' (177.1 mg GAE $100 \mathrm{~g}^{-1} \mathrm{fw}$ ), 'Roxana' (123.9 mg GAE $100 \mathrm{~g}^{-1} \mathrm{fw}$ ), 'Çağataybey' (93.9 mg GAE $100 \mathrm{~g}^{-1}$ $\mathrm{fw}$ ), and 'Super Gold' (88.9 mg GAE $100 \mathrm{~g}^{-1} \mathrm{fw}$ ) cultivars which are characterized by orange fruit color contained the highest levels of TP and TAC (10.6, 9.9, 9.8, and 12.3 mmol Fe ${ }^{2+} \mathrm{kg}^{-1} \mathrm{fw}$, respectively) among the studied cultivars. These cultivars have very different genetic originating from diverse regions including Turkey ('Alata Yıldizı' and 'Çağataybey'), Afghanistan ('Roxana'), and South Africa ('Super Gold').

The early apricot cultivars 'Precoce de Tyrinthe,' 'Septik', 'Ninfa', and 'Aurora' had the lowest TP and TAC contents. These results were in agreement with those of Hegedũs et al. (2010), who reported that total phenolics of early apricot cultivars were low. The TP contents of the cultivars were lower than that of other studies on commercial apricot cultivars (Drogoudi et al., 2008), but values higher than those reported by Leccese et al. (2010), Sochor et al. (2010), and Schmitzer et al. (2011). The TAC levels in this study were much higher than those reported by Sochor et al. (2010). Also, the growing season contributed significantly to the levels of TP and TAC of apricot fruits. The TP and TAC contents were higher in 2010 growing season $\left(75.1 \mathrm{mg} \mathrm{GAE} 100 \mathrm{~g}^{-1} \mathrm{fw}\right.$ and $7.7 \mathrm{mmol}$ $\mathrm{Fe}^{2+} \mathrm{kg}^{-1} \mathrm{fw}$ ). This might be due to climatical differences between 2010 and 2011 growing seasons. The 2010 growing season was generally warmer and drier. In May 2010, temperature was reached at $36^{\circ} \mathrm{C}$. These results agreed with those of Moretti et al. 2010, who reported when the high temperatures occur on apricot trees, the influences of the temperature might induce the accumulation of phenolic compounds in plant tissues.

The levels of fructose (FRUC), glucose (GLUC), sucrose (SUC), and total sugar in the apricot cultivars are given in Tab. 5. The main factor affecting levels of FRUC, GLUC, SUC, and total sugars was cultivar $(46.7,41.3$, 66.9 , and $64.8 \%$, respectively). The growing season and interaction of cultivar $\times$ season also affected to the sugar composition in minor levels, significantly. Growth environment influences the level of specific sugars and fruit acidity, but the profile of those sugars and acids is relatively constant across the environments (Ledbetter et al., 2006). The SUC and GLUC concentrations averaged 5.2 and 
Tab. 5. Effect of cultivar and season on phytochemical and sugar properties of some apricot cultivars

\begin{tabular}{|c|c|c|c|c|c|c|}
\hline Variable & $\begin{array}{c}\text { TP } \\
\text { mg.GAE } 100 \mathrm{~g}^{-1} \text { of } \mathrm{fw}\end{array}$ & $\begin{array}{c}\text { TAC } \\
\mathrm{mmol} \cdot \mathrm{Fe}^{2+} \mathrm{kg}^{-1} \text { of } \mathrm{fw}\end{array}$ & $\begin{array}{c}\text { FRUC } \\
\mathrm{g} 100 \mathrm{~g}^{-1} \text { of } \mathrm{fw}\end{array}$ & $\begin{array}{c}\text { GLUC, } \\
\mathrm{g} 100 \mathrm{~g}^{-1} \text { of } \mathrm{fw}\end{array}$ & $\begin{array}{c}\text { SUC, } \\
\mathrm{g} 100 \mathrm{~g}^{-1} \text { of } \mathrm{fw}_{\mathrm{w}}\end{array}$ & 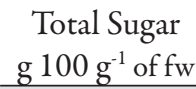 \\
\hline \multicolumn{7}{|c|}{ Cultivar } \\
\hline 'Antonio Errani' & $52.9 \mathrm{ef}^{\mathrm{a}}$ & $6.0 \mathrm{~cd}$ & $1.3 \mathrm{~cd}$ & 2.6def & $4.9 \mathrm{~cd}$ & $8.8 \mathrm{cde}$ \\
\hline 'Aurora' & $28.5 \mathrm{fg}$ & $3.3 e$ & $0.8 \mathrm{def}$ & $2.7 \mathrm{de}$ & $5.5 \mathrm{bcd}$ & $8.9 \mathrm{cde}$ \\
\hline 'Bebeco' & $68.8 \mathrm{cde}$ & $6.6 \mathrm{~cd}$ & $0.7 \mathrm{ef}$ & $3.0 \mathrm{bcd}$ & $5.9 \mathrm{~b}$ & $9.7 \mathrm{bcd}$ \\
\hline 'Harcot' & $59.1 \mathrm{de}$ & $7.9 \mathrm{bc}$ & $1.2 \mathrm{cde}$ & $2.8 \mathrm{~cd}$ & $5.8 \mathrm{bc}$ & $9.8 \mathrm{bcd}$ \\
\hline 'Roxana' & $123.9 \mathrm{~b}$ & $9.9 \mathrm{ab}$ & $1.6 \mathrm{bc}$ & 2.6def & $4.9 \mathrm{~cd}$ & $9.0 \mathrm{cde}$ \\
\hline 'Ninfa' & $28.2 \mathrm{fg}$ & $4.9 \mathrm{de}$ & $0.9 \mathrm{def}$ & $1.9 \mathrm{efg}$ & $5.8 \mathrm{bc}$ & $8.7 \mathrm{de}$ \\
\hline 'Super Gold' & $88.9 \mathrm{c}$ & $12.3 \mathrm{a}$ & $1.6 \mathrm{cde}$ & $3.5 \mathrm{abc}$ & $5.8 \mathrm{bc}$ & $10.4 \mathrm{~b}$ \\
\hline 'Precoce de Tyrinthe' & $21.2 \mathrm{~g}$ & 4.1de & $0.6 f$ & 2.1efg & $5.2 \mathrm{bcd}$ & 7.9ef \\
\hline 'Alata Yıldızı' & $177.1 \mathrm{a}$ & $10.6 \mathrm{ab}$ & $1.5 \mathrm{bc}$ & $3.5 \mathrm{ab}$ & $4.9 \mathrm{~cd}$ & $10.0 \mathrm{bc}$ \\
\hline 'Çağataybey' & $93.9 \mathrm{c}$ & $9.8 \mathrm{ab}$ & $2.8 \mathrm{a}$ & $3.1 \mathrm{bcd}$ & $7.5 \mathrm{a}$ & $13.4 \mathrm{a}$ \\
\hline 'Çağrıbey' & $41.4 \mathrm{efg}$ & $8.4 \mathrm{bc}$ & $0.9 \mathrm{def}$ & $2.9 \mathrm{bcd}$ & $4.6 \mathrm{~d}$ & $8.4 \mathrm{e}$ \\
\hline 'Dr Kaşka' & $82.3 \mathrm{~cd}$ & $8.1 \mathrm{bc}$ & $1.9 \mathrm{~b}$ & $3.8 \mathrm{a}$ & $1.2 \mathrm{e}$ & $6.9 \mathrm{f}$ \\
\hline 'Septik' & $21.6 \mathrm{~g}$ & $2.3 \mathrm{e}$ & $1.3 \mathrm{~cd}$ & $1.9 \mathrm{gf}$ & $5.3 \mathrm{bcd}$ & 8.6de \\
\hline 'Şahinbey' & $14.4 \mathrm{~g}$ & $4.7 \mathrm{de}$ & $0.9 \mathrm{def}$ & $1.4 \mathrm{~g}$ & $5.6 b c$ & $7.8 \mathrm{ef}$ \\
\hline Mean & 64.4 & 7.1 & 1.2 & 2.7 & 5.2 & 9.1 \\
\hline \multicolumn{7}{|c|}{ Season } \\
\hline 2010 & $75.1 \mathrm{a}$ & $7.7 \mathrm{a}$ & $1.3 \mathrm{a}$ & 2.7 & $5.5 \mathrm{a}$ & $9.6 \mathrm{a}$ \\
\hline 2011 & $53.7 \mathrm{~b}$ & $6.4 \mathrm{~b}$ & $1.2 \mathrm{~b}$ & 2.6 & $4.8 b$ & $8.7 \mathrm{~b}$ \\
\hline $\mathrm{HSD}_{\text {Cultivar (C) }}$ & 27.6 & 2.5 & 0.54 & 0.70 & 0.9 & 1.3 \\
\hline $\mathrm{HSD}_{\text {Scason }(S)}$ & 5.9 & 0.5 & 0.09 & ns & 0.2 & 0.2 \\
\hline $\mathrm{HSD}_{\mathrm{CxS}}$ & 23.2 & 2.8 & 2.61 & 0.14 & 1.8 & 1.9 \\
\hline \multicolumn{7}{|c|}{ ANOVA (mean square) } \\
\hline Cultivar (C) & $12721.6^{* *}$ & $53.2^{* *}$ & $1.99^{* *}$ & $2.77^{* *}$ & $10.9^{* *}$ & $14.1^{* *}$ \\
\hline Season $(S)$ & $9630.7^{* *}$ & $34.3^{* *}$ & $0.24^{*}$ & $0.01 \mathrm{~ns}$ & $10.8^{* *}$ & $13.5^{* *}$ \\
\hline $\mathrm{CxS}$ & $1654.3^{* *}$ & $4.8^{*}$ & $0.65^{* *}$ & $1.05^{* *}$ & $1.5^{* *}$ & $1.69^{*}$ \\
\hline Error & 186.1 & 1.6 & 0.1 & 0.1 & 0.2 & 0.4 \\
\hline \multicolumn{7}{|c|}{ Variance component distributions (\%) } \\
\hline Cultivar (C) & 68.1 & 70.5 & 46.7 & 41.3 & 66.9 & 64.8 \\
\hline Season $(S)$ & 7.0 & 0.5 & 20.1 & 20.0 & 9.5 & 8.8 \\
\hline CxS & 18.1 & 9.0 & 18.0 & 21.1 & 18.4 & 13.2 \\
\hline Error & 6.7 & 14.3 & 15.2 & 17.5 & 5.2 & 13.2 \\
\hline
\end{tabular}

Explanation was displayed in Tab. 2.. TP: total phenolics, TAC: total antioxidant capacity, FRUC: Fructose, GLUC: glucose, SUC: sucrose, fw: fruit weight

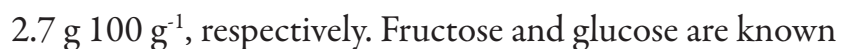
as the main sources of energy and sweetness. The cultivar 'Çağataybey' had the highest SUC (7.5 g $100 \mathrm{~g}^{-1}$ of $\left.\mathrm{fw}\right)$, FRUC (2.8 g $100 \mathrm{~g} \mathrm{~g}^{-1}$ of $\mathrm{fw}$ ), and total sugar (13.4 g 100 $\mathrm{g}^{-1}$ of $\mathrm{fw}$ ), similar to TSS content. Schmitzer et al. (2011) reported that total sugars as the constituents of sweetness is an important factor contributing to the internal quality and one of the most important objectives in apricot breeding studies. Thus, 'Çağataybey' was very promising for fresh apricot cultivation. The highest level of GLUC was found for 'Dr Kaşka' (3.8 g $100 \mathrm{~g}^{-1}$ of fw). Generally, the FRUC was detected in small amounts, averaging $1.2 \mathrm{~g}$ $100 \mathrm{~g}^{-1}$ of fw. The SUC ( 57\%) and GLUC ( 44\%) were found to be dominant sugars in all cultivars tested. These results agreed with the other studies suggesting that major sugars of apricot cultivars were sucrose, glucose, and fructose, respectively (Durmaz et al., 2010). Turkish apricot cultivars had higher total sugar concentrations than the other cultivars in this study. This result was similar to those of Paydas et al. (2010), who reported that the level of sugar in Turkish local apricot cultivars was higher than the European apricot cultivars. The sugar contents of the samples were lower than those of other studies on commercial apricot cultivars (Gurrieri et al., 2001; Paydas et al., 2010), but similar to those reported by Schmitzer et al. (2011) and Drougoudi et al. (2008). Besides, Turkish apricot cultivars that are hybrid of 'Sakıt' group and 'P. de Colomer' had the different sugar profiles. These results agreed with those of Ledbetter et al. (2006), who reported that the diverse and independent segregations of specific sugars upon hybridization are performed among apricots having different sugar compositions. 
292

\section{Correlations between variables}

Significant correlations were found between some fruit qualities and phytochemical properties, except for the TP showing significant correlation $(p<0.01)$ only with the TAC $(r=0.80)$ capacity (Tab. 6). The results showed that TP is important bioactive compounds for the antioxidant capacity of apricots. All pomological traits did not correlate with the TP and TAC parameters. An interesting result was that the fruit peel color characteristics were not correlated with these characters. It can be due to the apricot cultivars having similar fruit peel colors such as yellow-green, yellow, and orange. Hence, the pomological characters of the fruit species such as apricots, which have similar fruit color groups, could have limited utility for highlighting the correlations with phytochemical characteristics.

This finding was in agreement with those of Ruiz et al. (2005), who showed that phenolic content of apricot fruits was not related to fruit color. Neither total phenolics nor any specific class of phenolic compounds (procyanidins, hydroxycinnamic acid derivatives, flavonols, or anthocyanins) could be correlated with fruit color $h^{\circ}$, or other color coordinates. Thus, if the breeder's purpose is to identify apricots with particular levels of phenolic compounds, direct extractions of these compounds are the only means of determining specific quantities. Moreover, the FRUC and SUC values showed positively significant correlations with TP $(r=0.55$ and $r=0.69$, at $p<0.05$, respectively), while GLUC was correlated with TAC ( $r=$ 0.72 , at $p<0.01)$. Pirie and Mullins (1977) reported a good correlation in grapes between sugar content in berries and levels of phenolic substances, because of the role of sugars in the regulation of phenolic biosynthesis.
The fruit weight was significantly correlated with pit weight $(r=0.72$, at $p<0.05)$. There were no correlations between firmness and other fruit quality attributes such as fruit weight, fruit diameter, TSS, and phytochemical properties (data not shown). These results were in agreement with previous studies in apricots (Ruiz and Egea, 2008; Lo Bianco et al., 2010). Abidi et al (2011) reported that firmness was significantly correlated with SSC, $\mathrm{pH}$, and TSS/Acidity attributes among peach progeny, but these correlations were not found among the same fruit quality properties in apricots.

Ledbetter (2008) suggested that taste panels should be used in conducting correlation studies between organoleptic quality and both the levels of sugars and acids present in fruit. Fruit peel $a^{*}$ and $b^{o}$ values were found to be moderately correlated with attractiveness and taste of apricots (Tab. 6). The $b^{o}$ values were negatively related to attractiveness and taste in apricot cultivars, whereas $\mathrm{a}^{*}$ values were positively correlated with these quality parameters. Ruiz and Egea (2008) reported that $b^{\circ}$ values of peel and flesh color of apricots did not correlate with attractiveness, whereas it was inversely correlated with fruit taste. These results could be due to the differences in apricot cultivars studied and the size of the group of the cultivars. Further, fruit taste was correlated with TSS, TSS/Acidity, L*, and attractiveness. The blush color did not correlate with all the studied variables. These relations were found between peel color $\mathrm{a}^{*}$ and TSS, or TSS/Acidity, which agree with previous studies (Badenes et al., 1998; Ruiz and Egea, 2008). No correlations between fruit weight and TSS, or TSS/Acidity were observed, in agreement with previous studies on apricot (Ruiz and Egea, 2008). In addition, TSS was positively correlated with fruit peel color $\mathrm{a}^{*}$, FRUC, and SUC. The results agreed with those of Gurrieri et al.

Tab. 6. Correlation matrix for the studied variables

\begin{tabular}{|c|c|c|c|c|c|c|c|c|c|c|c|c|c|c|c|c|c|c|}
\hline Variable & $\mathrm{FD}^{\mathrm{a}}$ & PW & TSS & TSS/A & $\mathrm{L}$ & $\mathrm{a}$ & $\mathrm{b}$ & $C$ & $b^{o}$ & A & Taste & Blush & $\mathrm{TP}$ & TAC & FRUC & GLUC & SUC & TS \\
\hline $\mathrm{FW}$ & $0.95^{* *}$ & $0.72^{*}$ & -0.03 & -0.14 & 0.09 & -0.17 & 0.11 & 0.16 & 0.04 & -0.47 & -0.36 & 0.45 & 0.28 & 0.19 & -0.09 & -0.09 & 0.10 & 0.01 \\
\hline $\mathrm{KW}$ & & 1 & 0.03 & -0.01 & 0.19 & -0.05 & 0.28 & 0.32 & 0.06 & -0.41 & -0.42 & 0.41 & 0.07 & 0.06 & 0.04 & -0.14 & -0.02 & -0.1 \\
\hline TSS & & & 1 & $0.67^{* *}$ & -0.27 & $0.73^{*}$ & -0.1 & 0.15 & -0.47 & 0.35 & $0.59^{*}$ & 0.02 & 0.40 & 0.49 & $0.55^{*}$ & 0.47 & $0.61^{*}$ & $0.90^{* *}$ \\
\hline TSS/A & & & & 1 & -0.20 & $0.53^{*}$ & -0.02 & 0.14 & -0.43 & 0.49 & $0.64^{*}$ & -0.20 & -0.00 & 0.19 & 0.12 & 0.11 & $0.69^{*}$ & $0.65^{*}$ \\
\hline L & & & & & 1 & -0.38 & $0.86^{* *}$ & $0.80^{* *}$ & $0.65^{*}$ & -0.39 & $-0.69^{*}$ & -0.14 & 0.14 & 0.07 & -0.25 & 0.25 & -0.27 & -0.2 \\
\hline A & & & & & & 1 & -0.26 & -0.01 & $-0.85^{* *}$ & $0.64^{*}$ & $0.58^{*}$ & -0.03 & -0.00 & 0.18 & 0.46 & 0.09 & $0.55^{*}$ & $0.65^{*}$ \\
\hline B & & & & & & & 1 & $0.94^{* *}$ & $0.55^{*}$ & -0.2 & -0.46 & -0.05 & 0.05 & 0.16 & -0.45 & 0.19 & -0.12 & -0.2 \\
\hline$C$ & & & & & & & & 1 & 0.32 & -0.09 & -0.3 & -0.07 & 0.17 & 0.30 & -0.22 & 0.24 & 0.08 & 0.09 \\
\hline$b^{o}$ & & & & & & & & & 1 & $-0.66^{*}$ & $-0.67^{*}$ & 0.07 & 0.17 & -0.06 & -0.38 & 0.23 & -0.52 & -0.5 \\
\hline A & & & & & & & & & & 1 & $0.79^{* *}$ & -0.26 & -0.2 & 0.08 & 0.08 & -0.16 & $0.54^{*}$ & 0.4 \\
\hline Taste & & & & & & & & & & & 1 & -0.23 & -0.00 & 0.17 & 0.22 & -0.06 & $0.65^{*}$ & $0.58^{*}$ \\
\hline Blush & & & & & & & & & & & & 1 & 0.27 & 0.22 & 0.01 & -0.07 & -0.09 & -0.1 \\
\hline TP & & & & & & & & & & & & & 1 & $0.80^{* *}$ & $0.55^{*}$ & $0.69^{*}$ & -0.03 & 0.47 \\
\hline TAC & & & & & & & & & & & & & & 1 & 0.49 & $0.72^{* *}$ & 0.03 & 0.5 \\
\hline FRUC & & & & & & & & & & & & & & & 1 & 0.48 & 0.05 & $0.60^{*}$ \\
\hline GLUC & & & & & & & & & & & & & & & & 1 & -0.21 & 0.43 \\
\hline SUC & & & & & & & & & & & & & & & & & 1 & $0.74^{*}$ \\
\hline
\end{tabular}

\footnotetext{
${ }^{* * *}$ : Correlations significant at $p<0.05$ and $p<0.01$, respectively. ${ }^{2}$ Explanation was displayed in Tab. 2 and 5
} 
(2001), who reported that sucrose level was well-correlated with total soluble solids. In contrast to the above results, fruit peel a* values negatively correlated with FRUC, GLUC, and SUC contents in other fruit species (Çalişkan and Polat, 2011). This shows that orange, or red peel color apricot cultivars have higher SUC and total sugars. Besides, total sugars showed a significant positive correlation with TSS, TSS/Acidity, FRUC, and SUC, indicating that higher total sugars and sucrose levels meant for a higher TSS content.

The results showed that new Turkish apricot cultivars hybridization between Irano-Caucasian eco-geographical group and European eco-geographic group were very promising for fresh consumption. The results correspond well to those of Ledbetter et al. (2008), reporting that breeding programs based on apricots from the European eco-geographic group could benefit substantially in the development of higher quality fruit by using germplasm from other eco-geographical groups. The cultivars 'Çağataybey', 'Çağrıbey', and 'Alata Yıldızı' that have the same pollinator ('Sakit' x 'P. de Colomer') had different fruit quality and phytochemical properties, but the cultivars, generally, were similar to fruit quality characteristics of the Sakit group. Akpinar et al. (2010) reported that the relatively high genetic similarity $(75 \%)$ via microsatellite analysis is found between 'Çağrıbey' ('Sakıt-6' x 'P. de Colomer' cross) and 'Çağataybey' ('Sakıt-2' x 'P. de Colomer'). These results could be attributed to the fact that these two cultivars have the same pollinator. Besides, according to SRAP (sequence-related amplification polymorphism), based on genetic analyses, 'Çağribey' and 'Çağataybey' were similar group with their parents, but these cultivars were closer to 'Sakıt 2' than 'P. de Colomer' (Akpinar et al., 2010). Thus, we can suggest that these cultivars with high TSS and red blush color were much similar to Sakıt 2. Similar results were reported by Couranjou (1995) that good genetic gain is possible in apricot breeding by choosing parents based on fruit phenotype. Thus, parental apricots are used in hybridizations that are markedly superior in specific aspects of fruit quality generally pass along those quality characteristics to the next generation of seedlings.

\section{Conclusions}

This study was conducted to evaluate some fruit quality and phytochemical properties of new Turkish cultivars, hybrid between Irano-Caucasian eco-geographical group and European eco-geographic group and important apricot cultivars. The data showed that considerable variations existed in fruit quality and phytochemical characteristics, and sugar compositions of the apricot cultivars based on cultivar, growing season and cultivar $\times$ season interactions. However, genotypic effect was most significant on variables studied, except for $\mathrm{pH}$, acidity, and TSS/Acidity. The new hybrid cultivar 'Çağataybey' contained the highest TSS percentage, it was rich TP and TAC levels, and had above $50 \%$ of blush color on the fruit peel. These levels were appreciably higher among the cultivars studies. These results demonstrated that Turkish Sakıt apricots, especially Sakıt 2 that belongs to the Irano-Caucasian ecogeographical group can readily transfer to their progeny for high TSS and blush color on fruit peel when it was hybridized with European eco-geographic group apricots. The data could be useful for new apricot breeding studies among different eco-geographical group.

\section{References}

Abbott JA (1999). Quality measurement of fruits and vegetables. Postharvest Biol Tech 15:207-225.

Abidi W, Jiménez S, Moreno MÁ, Gogorcena Y (2011). Evaluation of antioxidant compounds and total Sugar content in a nectarine [Prunus persica (L.) Batsch] progeny. Int J Molec Sci 12:6919-6935.

Akpinar AE, Koçal H, Ergul A, Kazan K, Şelli ME, Bakir M, Aslantaş Ş, Kaymak S, Saribaş R (2010). SSR-based molecular analysis of economically important Turkish apricot cultivars. Genet Mol Res 9(1):324-332.

Asma BM, Ozturk K (2005). Analysis of morphological, pomological and yield characteristics of some apricot germplasm in Turkey. Genet Res Crop Evol 52:305-313.

Audergon JM, Reich M, Souty M (1991). Abricot. Les variations des critéres de qualité. Arboriculture Fruitiére 436:35-46.

Ayanoglu H, Kaska N, Yildiz A (1995). Investigations on adaptations of early apricot cultivars in Mediterranean region. Proceedings of the Second National Horticultural Congress, p.159-163, Adana, Turkey.

Badenes ML, Martinez-Calvo J, Llácer G (1998). Analysis of apricot germplasm from the European Eco-geographical group. Euphytica 102(1):93-99.

Bassi D, Bartolozzi F, Muzzi E (1996). Patterns and heritability of carboxylic acids and soluble sugars in fruits of apricot (Prunus armeniaca L.). Plant Breed 115:67-70.

Beccaro G, Mellano MG, Botta R, Chiabrando V, Bounous G (2006). Phenolic and anthocyanin content and antioxidant activity in fruits of bilberry (Vaccinium myrtillus L.) and of highbush blueberry (Vaccinium corymbosum L.) cultivars in north western Italy. Acta Hort 715:553-558.

Camara MM, Diez C, Torija ME (1996). Free sugars determination by HPLC in pineapple products. Z Lebensm Unters Forsch 202:233-237.

Couranjou J (1995). Genetic studies of 11 quantitative characters in apricot. Sci Hort 61(1):61-75.

Crisosto CH, Garner D, Crisosto GM, Bowerman E (2004). Increasing 'Blackamber' plum (Prunus salicina Lindley) consumer acceptance. Postharvest Biol Technol 34(3):237244.

Çalişkan O, Polat AA (2011). Phytochemical and antioxidant properties of selected fig (Ficus carica L.) accessions from the eastern Mediterranean region of Turkey. Sci Hort 128(4):473-478.

Dragovic-Uzelac V, Levaj B, Mrkic V, Bursac D, Boras M (2007). 
294

The content of polyphenols and carotenoids in three apricot cultivars depending on stage of maturity and geographical region. Food Chem 102(3):966-75.

Drogoudi PD, Vemmos S, Pantelidis G, Petri E, Tzoutzoukou C, Karayiannis I (2008). Physical characters and antioxidant, sugar, and mineral nutrient contents in fruit from 29 apricot (Prunus armeniaca L.) cultivars and hybrids. J Agric Food Chem 56(22):10754-10760.

Durmaz G, Çam M, Kutlu T, Hişil Y (2010). Some physical and chemical changes during fruit development of five common apricot (Prunus armeniaca L.) cultivars. Food Sci Tech Res 16(1):71-78.

Egea J, Romojaro F, Pretel MT, Martinez-Madrid MC, Costell E, Cascales A (2006). Application of sensory analysis to the determination of the optimum quality and harvesting moment in apricots. Acta Hort 701:529-532.

Ercisli S (2009). Apricot culture in Turkey. Sci Res Essay 4:715719.

Francis FJ (1980). Color quality evaluation of horticultural crops. HortSci 15:58-59.

Gurrieri F, Audergon JM, Albagnac G, Reich M (2001). Soluble sugars and carboxylic acids in ripe apricot fruit as parameters for distinguishing different cultivars. Euphytica 117:183189

Hegedũs A, Engel R, Abrankó L, Balogh E, Blázovics A, Hermán R, Halász J, Ercisli S, Pedryc A, Stefanovitsbányai É (2010). Antioxidant and antiradical capacities in apricot (Prunus armeniaca L.) fruits: Variations from genotypes, years, and analytical methods. J Food Sci 75(9):C722-C730.

IPGRI, CEC (1984). Revised descriptor list for apricot (Prunus Armeniaca). Editors: Guerriero R., Watkins R. International Board for Plant Genetic Resources Commission of European Communities, Committee on Disease Resistance Breeding and use of Genebanks. Rome, Italy.

Kader AA (1999). Fruit maturity, ripening, and quality relationships. Acta Hort 484:203-208.

Leccese A, Bartolini S, Viti R (2008). Total antioxidant capacity and phenolics content in fresh apricots. Acta Aliment Hung 37:65-76.

Leccese A, Bureau S, Reich M, Renard MGCC, Aon JM, Mennone C, Bartolini S, Viti R (2010). Pomological and nutraceutical properties in apricot fruit: cultivation systems and cold storage fruit management. Plant Foods Human Nutr 65:112-120.

Ledbetter C, Peterson S, Jenner J (2006). Modification of sugar profiles in California adapted apricots (Prunus armeniaca L.) through breeding with Central Asian germplasm. Euphytica 148:251-259.

Ledbetter C (2008). Apricots, p. 460. In: Hancock JF (Eds.). Temperate fruit crop breeding: Germplasm to genomics, Oregon.

Lo Bianco R, Farina V, Indelicato SG, Filizzola F, Agozzino P (2010). Fruit physical, chemical and aromatic attributes of early, intermediate and late apricot cultivars. J Sci Food Agric 90(6):1008-1019.

Madrau MA, Piscopo A, Sanguinetti AM, Del Caro A, Poiana
M, Romeo FV, Piga A (2009). Effect of drying temperature on polyphenolic content and antioxidant activity of apricots. Eur Food Res Techol 228 (3):441-448.

Milošević T, MiloševićN, Glišić I, Krška B (2010). Characteristics of promising apricot (Prunus armeniaca L.) genetic resources in Central Serbia based on blossoming period and fruit quality. HortSci 37(4):46-55.

Moretti CL, Mattos LM, Calbo AG, Sargent SA (2010). Climate changes and potential impacts on postharvest quality of fruit and vegetable crops: a review. Food Res Int 43(7):1824-32.

Mori K, Goto-Yamamoto N, Kitayama M, Hashizume K (2007). Loss of anthocyanins in red-wine grape under high temperature. J Exper Bot 58(8):1935-1945.

Paydas S, Yilmaz KU, Kafkas E (2010). Detection of sugar composition of some apricot cultivars by high performance liquid chromatography. Acta Hort 862:583-586.

Pellegrini N, Serafini M, Colombi B, Del Rio D, Salvatore S, Bianchi M, Brighenti F (2003). Total antioxidant capacity of plant foods, beverages and oils consumed in Italy assessed by three different in vitro assays. J Nutr 133(9):2812-2819.

Pirie A, Mullins MG (1977). Interrelationships of sugars, anthocyanins, total phenols and dry weight in the skin of grape berries during ripening. Am J Enol Vitic 28(4):204209.

Polat AA, Caliskan O (2008). Fruit characteristics of table fig (Ficus carica) cultivars in subtropical climate conditions of the Mediterranean region. NZ J Crop Hort Sci 36(2):107-115.

Polat AA, Caliskan O (2010). Determination of growth and fruit quality parameters of some apricot cultivars in subtropical climate conditions of Turkish Mediterranean region Acta Hort 862:323-330.

Radi M, Mahrouz M, Jaouad A, Tacchini M, Aubert S, Hugues M, Amiot MJ (1997). Phenolic composition, browning susceptibility, and carotenoid content of several apricot cultivars at maturity. HortSci 32(6):1087-1091.

Ruiz D, Egea J, Tomas-Barberan FA, Gil M (2005). Carotenoids from new apricot (Prunus armeniaca L.) varieties and their relationship with flesh and peel color. J Agric Food Chem 53(16):6368-6374.

Ruiz D, Egea J (2008). Phenotypic diversity and relationships of fruit quality traits in apricot (Prunus armeniaca L.) germplasm. Euphytica 163:143-158.

Ruml M, Vuković A, Milatović D (2010). Evaluation of different methods for determining growing degree-day thresholds in apricot cultivars. Int J Biometerol 54:41 1-422.

Schmitzer V, Slatnar A, Mikulic-Petkovsek M, Veberic R, Krskab B, Stampar F (2011). Comparative study of primary and secondary metabolites in apricot (Prunus armeniaca L.) cultivars. J Sci Food Agric 91(5):860-867.

Slinkard K, Singleton VL (1977). Total phenol analysis: automation and comparison with manual methods. Am J Enol Vitic 28(1):49-55.

Sochor J, Zitka O, Skutkova H, Pavlik D, Babula P, Krska B, Horna A, Adam V, Provaznik I, Kizek R (2010). Content of phenolic compounds and antioxidant capacity in fruits of apricot genotypes. Molecules 15:6285-6305. 